\title{
ISLAMIC BANK LISTED IN FINANCIAL MARKET: RISK, GOVERNANCE, EARNING, AND CAPITAL
}

\author{
Teguh Budiman ${ }^{1}$, Farida Titik Kristanti ${ }^{2}$, Wardhana ${ }^{3}$
}

\begin{abstract}
Islamic Bank Listed in Financial Market: Risk, Governance, Earning, and Capital. Islamic Bank is a bank that applies Islamic principles in running the business. Until 2015, there were 12 Islamic Bank in Indonesia; one of them already listed on the stock market. The purpose of this study was to analyze differences in the bank's soundness was assessed using a bank's risk profile, good corporate governance, income, and capital (RGEC) between listed Islamic Banks and the unlisted ones. Using the data period 2011-2015 used the independent t-test to test for differences. Statistical tests showed that there is no significant difference in credit risk as measured by NPF and Earning as measured by BOPO that represent cost efficiency between the two groups of companies. Listed Islamic banks have lower credit risk and greater efficiency than the unlisted ones.
\end{abstract}

Keywords: risk, governance, earning, capital

\begin{abstract}
Abstrak. Bank Syariah yang Terdaftar Pada Pasar Keuangan: Risiko, Tata Kelola, Pendapatan, dan Modal. Bank syariah adalah bank yang mengaplikasikan prinsip-prinsip syariah dalam menjalankan kegiatan bisnisnya. Hingga tahun 2015 terdapat 12 Bank Islamik di Indonesia, dimana salah satunya sudah terdaftar di pasar modal. Tujuan studi ini adalah menganalisis perbedaan kesehatan bank yang dinilai menggunakan profil risiko, tata kelola perusahaan yang baik, pendapatan, dan modal untuk Bank syariah yang terdaftar dengan yang tidak terdaftar di pasar modal Indonesia. Uji independen t digunakan untuk menguji perbedaan tersebut dengan menggunakan data periode 20112015. Hasil pengujian statistik menunjukkan ada perbedaan yang signifikan pada risiko kredit yang diukur dengan NPF dan Earning, diukur dengan BOPO yang mencerminkan efisiensi biaya, antara kedua kelompok perusahaan tersebut. Bank syariah yang terdaftar di pasar modal memiliki risiko kredit yang lebih kecil dan efisiensi yang lebih besar dibandingkan yang tidak terdaftar di Bursa Efek.
\end{abstract}

Kata kunci: risiko, tata kelola, pendapatan, modal 


\section{Introduction}

The role of the financial sector in the economy is crucial, particularly in the provision of funds for financing the economy (especially investment). Banking is one of the financial areas that expected to play an active role in national and regional economic development. Economic growth of a country is determined by many factors, one of them is the banking sector which has the principal function as an institution of the public fund (Kuncoro, 2002).

Islamic finance has shown tremendous growth in last two decades. The milestone, in growth and popularity of Islamic Financial Institutions (IFIs), was the Conference of Foreign Ministers of Muslim countries in 1973, where a decision of establishment of Islamic Development Bank (IDB) taken place (Hanif, 2011). In the Indonesia financial system, one of the banking types is the Islamic Bank that implements Islamic principles in running the company's operations. Islamic Bank in its development is expected to affect the growth of the Islamic finance industry. Islamic banking development in Indonesia started in 1991 when the establishment of the first Islamic commercial bank in Indonesia, Bank Mu'amalat Indonesia. Then, to accelerate the economic growth of Islamic banks in Indonesia, the government managed to make a full legal basis and the particular set of Islamic banking namely Law No. 21 of 2008 concerning Sharia Banking (Antonio, 2011). The number of Islamic banks in Indonesia is 12 banks, 22 business units, and 161 Islamic rural banks (Islamic Banking Statistics, June 2015). It shows the development of Islamic banks and indicates the high public demand for Islamic banking.

According to data from Islamic Banking Statistics in June 2015, the profit growth of Islamic banking industry in 2014, the Islamic banks only achieved a profit of IDR. 1.79 trillion, down by 46\% compared to the year 2013 profit of IDR. 3.3 trillion. Meanwhile, net profit is only IDR 1 trillion, down to $69 \%$ compared to the net profit in 2013 reached IDR 3.2 trillion. Meanwhile, in June 2015 , it also decreased by $38 \%$ to IDR 1.1 trillion compared to 2014 , but from regarding net profit, it increased by $31 \%$ compared to the year 2014 that reached IDR 1.3 trillion.

Islamic banks are required to have the level of soundness and sound financial performance to compete with the conventional banks. It can see the growth of the profit generated by Islamic banks; healthy earnings growth is a sign of good corporate performance. As a result, the healthy profit growth will increase the value of the company (Simorangkir, 2003). The size of net profit growth can see by comparing (ratio) between earnings in the current period with income in the previous period.

Associated with the soundness of banks, since 2011, Bank Indonesia has implemented the rating method Risk Based Bank Rating (RBBR) replacing the 
CAMELS Rating System. Based PBI No.13 / 1 / PBI / 2011 and SE No. 13/24 / DPNP on Assessment of Commercial Banks dated October 25, 2011. The method Risk Based Bank Rating (RBBR) or RGEC based on four factors including the Risk Profile (Risk Profile), Good Corporate Governance (GCG), Profitability (Earnings) and Capital (Capital). While the Regulation of Financial Services Authority No. 8 of 2014 on Bank Rating Islamic and Islamic Business Unit mentions that Islamic banks are required to assess the soundness of individual banks and consolidated with coverage assessment of the several factors. First, The risk profile (risk profile). Second, Good Corporate Governance. Third, Profitability (earning). Fourth, Capital (Capital). Assessment of the risk profile conducted on ten risks such as credit risk, market risk, liquidity risk, operational risk, legal risk, strategic risk, compliance risk, reputation risk, the risk of returns, and investment risk. Good Corporate Governance Assessment conducted in the management of Islamic Banks applies the principles of good corporate governance. Rating of earnings made to the profitability performance, sources of profitability and earnings stability (Sustainability Learning) Islamic Banks. Rating of capital done on the level of capital adequacy and capital management in Islamic Banks.

Research on the bank's soundness and the performance of Islamic banks in Indonesia have done since several years ago. Sofyan and Anggono (2015) conducted a study using data from 2005 to 2014 and multiple regression methods. The results showed the ratio of NIM, CAR significant and positive impact on profits, while the NPL ratio and LDR critical and adverse effect on profits. While Rotinsulu et.al. (2015) conducted a study on the state-owned bank in Indonesia in 2007 to 2013. The results showed that RBRR affects the profitability simultaneously. Credit risk and liquidity risk negatively impact profitability. Market risk adversely affects the profitability of capital while no effect on profitability.

Various studies that assess banks soundness differences also have been made in Indonesia. Lupa, et.al. (2016) found evidence that Islamic banks have better profitability and liquidity than the conventional ones. The study Fitriana, Rosyid and Fakhrina (2015) showed that there was no difference in the bank's soundness that rated by RGEC between Islamic banks and the conventional ones except on earnings variable. Astuti (2015) found evidence that there was a significant performance differences between the foreign banks and the National Bank. Foreign Bank has better CAR, LDR, and ROA, while National Bank has better BOPO. Putri and Damayanti (2013) found evidence that there were differences in risk profile and GCG between large banks and small banks, while profitability and capitalization did not show any differences. Other studies done by Anggraini, et.al (2015) which linked belong RBBR method found that the BRI Syariah is a healthy bank. 
Currently, the majority of existing Islamic banks are Islamic business units owned by conventional banks. With the ASEAN free market, the competition is not only to Indonesia but also from other ASEAN countries (mainly Malaysia). As the Islamic banking needs to improve the quality of their performance, one of which is the listed itself as a public company and sell shares on the capital market. Then, it could increase the bank's capital and also eventually will enhance the size of the enterprise. Moreover, one of the 12 existing Islamic banks in Indonesia today, Bank Panin Islamic Bank has just listed on the Indonesian Stock Exchange.

The fact indicates a curious phenomenon to see whether there are differences in the bank's soundness that rated by RGEC and performance between listed Islamic banks and the unlisted ones. This study aims to analyze whether there are differences in risk profile, good corporate governance, earnings and capital between listed Islamic banks and the unlisted ones.

\section{Literature Review}

Signaling theory used as the main argument in this study that states that management will naturally intentionally send signals to the market. The financial reporting and disclosure are potentially important means for management to communicate firm performance and governance to outside investors (Healy and Palepu, 2001). The most profitable bank will provide complete information and better for the market (Bini, et.al, 2011).

One way to understand the market signals issued by the banks is using the components RGEC to assess the performance of banks during a period that can be considered their soundness, based on the values obtained from the rating. It can then take corrective measures to reduce risk and avoid failure of these banks even further to prevent a financial crisis in the system of the Indonesian economy.

According to Bank Indonesia Regulation No.13/24/DPNP dated 25 October 2011. The Bank is required to conduct the assessment (self-assessment) of the Bank by using the approach of Risk (Risk-based Bank Ratings / RBBR) both individually and on a consolidated basis, the scope of assessment include the following factors: the risk profile (risk profile), Good Corporate Governance (GCG), profitability (earnings); and Capital (capital) to produce a composite rating of the Bank.

In assessing the soundness of a bank, OJK uses a qualitative approach to various aspects affecting the condition of a bank. Since 2011 up to now, methods used to assess the health of the banks are RBBR (Risk Based Bank Rating). Specifically, for Islamic banks, the OJK published the Regulation of the Financial 
Services Authority (Otoritas Jasa Keuangan) No. 08 / POJK.03 / 2014 of the Soundness Assessment Islamic Banks and Islamic Business Unit. Under these regulations, the soundness of banks is the result of the bank condition assessment conducted by the risks included risks related to the application of Islamic principles and the performance of the bank or so-called risk-based.

Based on the SE 13/24/ DNP on Rate for Commercial Banks, it can seen the explanation of all eight types of risks faced by the banking sector, namely: Credit Risk, Market Risk, Liquidity Risk, Operational Risk, Compliance Risk, Legal Risk, Reputation Risk, Strategic Risk. However, Islamic banks then were coupled with two risks, namely the yield risk and investment risk. Risks variables in this study are the credit risk, liquidity risk, and market risk because those risks can be measured quantitatively.

Following this research focus on Risk Profile, Good Corporate Governance, Earning and Capital (RGEC) ratios, the primary hypotheses of this study are: First, there is a difference between the credit risks of listed Islamic banks and the unlisted ones. Second, there is a difference between the liquidity risk listed Islamic banks and the unlisted ones. Three, there is a difference between the market risks of listed Islamic banks and the unlisted ones. Fourth, there is a difference between the NIM of listed Islamic banks and the unlisted ones. Fifth, there is a difference between the ROA of listed Islamic banks and the unlisted ones. Sixth, there is a difference between the NOM of listed Islamic banks and the unlisted ones. Seventh, there is a difference between the BOPO of listed Islamic banks and the unlisted ones. Eight, there is a difference between the CAR of listed Islamic banks and the unlisted ones.

\section{Methods}

The unit of analysis refers to the level of unity of data collected during the data analysis stage further (Sekaran, 2009). The units of analysis in this study are Islamic Banks (BUS) registered with the OJK during 2011-2015 by using comparative quantitative approach. While the comparative study is a study that is comparing, the variables are the same as independent variables research, but sampling more than one or in a different time. The population is a whole group of people, events, or interests of research object (Sekaran, 2009). In conducting this research, the study population is used all listed Islamic banks listed and unlisted ones during 2011-2015.

Purposive Random Sampling used with the following criteria: (1) Islamic commercial banks and registered at the OJK during the years 2011-2015. (2) 
Issuing financial statements ending on December 31, and have audited by a public accountant, released publicly in print and electronic media, as well as Indonesian banks listed in the directory published by Bank Indonesia and the OJK. (3) Availability of data needed in the research, which is required ratios, financial information, and other necessary data. Samples of companies that meet these criteria are as many as 11 Islamic banks. Bank of BTPN Sharia excluded from the sample because of the new turn into an Islamic commercial bank in 2014. From 11 banks only Panin Bank Syariah (BPS) already listed on the Indonesian Stock Exchange.

Table 1. List of Islamic Banks in Indonesia

\begin{tabular}{ccl}
\hline No & Code & \multicolumn{1}{c}{ Issuer } \\
\hline 1 & MUA & Bank Muamalat \\
2 & VIS & Bank Victoria Syariah \\
3 & BRIS & Bank Rakyat Indonesia Syariah \\
4 & BJBS & Bank BJB Syariah \\
5 & BNIS & Bank Negara Indonesia Syariah \\
6 & BMRS & Bank Mandiri Syariah \\
7 & BMS & Bank Mega Syariah \\
8 & BPS & Panin Bank Syariah \\
9 & BSK & Bank Syariah Bukopin \\
10 & BCS & Bank Central Asia Syariah \\
11 & MYS & Maybank Syariah \\
12 & BTPNS & Bank Tabungan Negara Syariah \\
\hline
\end{tabular}

Source :OJK, 2015

The t-test is used to check the relationship between the independent variable (which is a category or non-metric scale) and the dependent variable (which is continuous, metric or interval and ratio scale) (Ghozali, 2011). Due to two category of independent variables, the statistical test used the t-test. This test is used to determine whether two separate samples have the different value. The first step is the need to test assumed equal variance with the different one by looking the Levene test. If $\mathrm{F}$ Levene test has a probability of $>0.05$, it can concluded that the t-test should use equal variance assumed, and if the probability of $<0.05$ then t-test should use the different one (equal variance not assumed). The second step is to see the value of t-test to determine whether there are differences in the average value significantly 
or not. If the significance value> 0.05 , then there was no significant difference in the two groups of samples. Meanwhile, if the significance value $<0.05$ then it can be stated that there is a significant difference in the two groups of samples.

\section{Result and Discussion}

Statistical tests showed that the result of the probability of F Lavene test is simply the NPV of factors that need to use Equal Variance Assumed because it has the probability of 0,036 which is smaller than 0.05 . While, other factors such as FDR, VAP, NI, ROA, NOM, ROA and CAR using the different one (equal variance not assumed), because it has a probability greater than 0.05 .

The statistical result also showed that the only factor of credit risk as measured by the NPF and BOPO have significant differences in listed Islamic banks and unlisted ones. This result indicated by the significant number of both these factors are less than $0.05(\mathrm{NPF}$, sig. $=0.005$, and BOPO, sig. $=0.037)$. It proves the hypothesis that there are significant differences in credit risk (NPF) and BOPO between listed Islamic banks and the unlisted ones. Listed Islamic banks have a mean NPF (credit risk) amounted to $0.80 \%$ greater than the unlisted ones of $2.19 \%$. As for the BOPO, listed Islamic banks have a mean $71.19 \%$ which is smaller than unlisted ones of $90.86 \%$. ). It proves that there is a significant difference of BOPO between listed Islamic banks and the unlisted ones.

NPF (Non Performing Financing) is a ratio that indicates the ability of the bank to manage problem loans of total loans granted by banks. If the NPF increases, it will lead to an increase in problem loans, provide larger PPAP, declining incomes, profits suffered loss, reduced capital, and lower capital. NPF showed overall quality of credit assets, if NPF increases, it will cause an increase in nonperforming lending that requires larger the provision of PPAP and causing a declined revenues. This study proves that the listed Islamic banks have smaller NPF than the unlisted ones. This study due to the listed Islamic banks have obligations to give a good signal to the market (according to signaling theory); thus investors interested in buying their shares.

Listed Islamic banks also have smaller BOPO than the unlisted ones. BOPO is used to measure the efficiency and ability of banks to carry out their operations. The lower the level of BOPO ratio means the better performance of the bank's management because it is more efficient use of existing resources. However, every banking company will strive to generate as much profit. In addition to efficiency, in order to reduce operating expenses, the bank should be able to use all the financial capabilities as assets to generate earnings. This study found evidence that the listed banks are more efficient than the unlisted banks because they have lower BOPO. 
Tabel 2. Statistical Results

\begin{tabular}{lllll}
\hline & F test & Prob & $\begin{array}{l}\text { Equal Variance Assumed / Equal } \\
\text { Variance Not Assumed }\end{array}$ & Sig.(2 tailed) \\
\hline NPF & 4.625 & 0.036 & Equal Variance Not Assumed & 0.005 \\
FDR & 0.070 & 0.792 & Equal Variance Assumed & 0.477 \\
VAP & 0.819 & 0.370 & Equal Variance Assumed & 0.218 \\
\hline NI & 1.090 & 0.301 & Equal Variance Assumed & 0.344 \\
ROA & 0.224 & 0.638 & Equal Variance Assumed & 0.498 \\
NOM & 0.233 & 0.632 & Equal Variance Assumed & 0.603 \\
BOPO & 0.809 & 0.925 & Equal Variance Assumed & 0.037 \\
CAR & 0.368 & 0.547 & Equal Variance Assumed & 0.327 \\
\hline
\end{tabular}

Source: Estimation Results

Other factors such as FDR (liquidity risk), VAP (market risk), NI (corporate governance), NOM, ROA (Earning), and CAR (Capital) do not show any significant differences between listed Islamic banks are listed and the unlisted ones. The statistical result also indicates that the probability of FDR, VAP, NI, NOM, $\mathrm{ROA}$ and CAR greater than 0.05 , therefore there is no difference of all variable between listed Islamic banks and the unlisted ones.

FDR showed the bank's liquidity risk. The greater the company's ability to meet its short-term obligations, the higher the FDR. It means the liquidity risks of listed Islamic banks is $109.90 \%$; it is greater than the unlisted ones of $98.16 \%$. It shows that a listed Islamic bank is very liquid. High liquidity could lead to the opportunity cost for the banks. The theory states that there is always a tradeoff between liquidity and profitability, but it does not prove in this study. The performance of the bank as measured by ROA indicates that the listed Islamic bank has a better performance than those not listed. ROA of listed Islamic Bank is 1.87\%. Otherwise, unlisted Islamic Banks is 0.85\%.

Similarly, other factors such as the VAP which indicates the market risk. VAP is a form of control of the market risk that illustrates how much potential loss of Islamic Banks in the event of changes in exchange rates or changes in the value of the portfolio itself in the market. Listed Islamic banks have a mean of $26.74 \%$ than those which the unlisted ones that are equal to $21.79 \%$. It means listed Islamic banks have a greater potential loss in the event of changes in exchange rates or changes in the market value of the portfolio. However, it must keep in mind the principle of 
high-risk, high return. A significant risk will enable the company to produce large returns. The big risk is unlikely to worry because it followed with Islamic banks that have a better performance. The performance indicated by the average ROA of listed Islamic Banks better than the unlisted ones.

Table 3. Group Statistics

\begin{tabular}{|c|c|c|c|c|c|c|}
\hline & STATUS & & $\mathbf{N}$ & Mean & Std. Deviation & Std. Error Mean \\
\hline \multirow[t]{2}{*}{ NPF } & Not listed & & 50 & 2.1956 & 1.51789 & 0.21466 \\
\hline & Listed & & 5 & 0.8020 & 0.69518 & 0.31089 \\
\hline \multirow[t]{2}{*}{ FDR } & Not listed & & 50 & 98.1622 & 35.32809 & 4.99615 \\
\hline & listed & & 5 & 109.9000 & 30.19782 & 13.50488 \\
\hline \multirow[t]{2}{*}{ VAP } & Not listed & & 50 & 21.7982 & 8.62257 & 1.21942 \\
\hline & Listed & & 5 & 26.7460 & 6.26559 & 2.80206 \\
\hline \multirow[t]{2}{*}{ NI } & Not listed & & 50 & 6.4676 & 2.85076 & 0.40316 \\
\hline & Listed & & 5 & 5.2260 & 1.48811 & 0.66550 \\
\hline \multirow[t]{2}{*}{ ROA } & Not listed & & 50 & 0.8504 & 3.32532 & 0.47027 \\
\hline & Listed & & 5 & 0.8780 & 0.98223 & 0.43927 \\
\hline \multirow[t]{2}{*}{ NOM } & Not listed & & 50 & 0.2008 & 4.86426 & 0.68791 \\
\hline & Listed & & 5 & 1.3500 & 0.64807 & 0.28983 \\
\hline \multirow[t]{2}{*}{ BOPO } & Not listed & 50 & & 8630 & 19.84286 & 2.80620 \\
\hline & Listed & 5 & & 1940 & 15.79148 & 7.06216 \\
\hline \multirow[t]{2}{*}{ CAR } & Not listed & 50 & & 1686 & 14.67733 & 2.07569 \\
\hline & Listed & 5 & & 8440 & 10.31932 & 4.61494 \\
\hline
\end{tabular}

Variable of Good Corporate Governance (GCG) represented by financial ratios (NI) which describe the level of income the amount of the distribution of funds obtained by the use of productive assets owned by Islamic Banks. Although there was no statistically significant difference between the NI listed Islamic banks are listed and the unlisted ones, Mean of NI listed Islamic banks at 5.22\% turned out to be relatively small compared with the unlisted ones, amounting $6.46 \%$. NI of listed Islamic bank is relatively smaller, but it does not mean that governance of them worse. Performance listed Islamic bank as measured by ROA proved to be better than the unlisted ones. Although there is no statistically significant difference 
between the ROA for listed and unlisted Islamic banks, however, the listed Islamic Banks have larger ROA than not listed (1.88\% compared $0.85 \%)$. ROA is used to measure the bank's ability to make a profit overall. It means that the ability of listed Islamic banks in generating profits on the whole better than the unlisted ones, although there is no statistically significant difference.

A key ratio used to assess the profitability of Islamic banks is by using Net Operating Margin (NOM). NOM is used to determine the ability of productive assets in generating profit. The result is that there is no significant difference between NOM of listed Islamic bank and the unlisted ones. However NOM of listed Islamic banks, at $1.35 \%$, are greater than those that unlisted, that is equal to 0.44 . It means that listed Islamic banks have better performance in generating profits from its productive assets than the unlisted ones.

CAR also showed that there is no significant difference between the two groups of banks, even though listed Islamic banks have higher CAR than the unlisted ones (28.24\% compared to $22.19 \%)$. CAR is an indicator to assess aspects of capital in a bank. There is a capital component and Risk Weighted Assets (RWA) in its calculations. Higher capital will increase the ratio of CAR, which means Islamic Banks have sufficient capital and can cover losses from the activity of Islamic Banks. The increase in equity capital, in particular, is going to lower the cost of funds. The increasing is because the Islamic Banks can use their capital to allocated to the assets, which are then able to increase the profitability of Islamic Banks.

The result shows that from some indicators, there is no difference between the listed bank and non-listed banks. This result arises because only one Islamic bank which already listed on stock exchange. But, listed on the stock exchange can be one of the strategies to the capital strengthened in Islamic banks. As we know, the regulator right now is forced Islamic business unit to the spin-off. The spin-off policy according to Al Arif (2015) had an effect on the efficiency of the Islamic banks. The regulator should focus to create a healthy Islamic bank in Indonesia.

\section{Conclusion}

This study shows evidence that the listed Islamic bank has a better performance than the unlisted ones. This is due, companies that have gone public have an obligation always to give a good signal to the market that done by giving a good performance, so investors are interested in investing in the bank. There is a significant difference for credit risk that measured by Non Performing Finance and BOPO that represent cost efficiency, between listed Islamic banks listed and the unlisted ones. Listed Islamic Banks show a better efficiency on both factors. 
Listed banks give a good signal to investors in the capital market through good performances in their financial statements. In this study, a good signal represented by low values of NPF and BOPO. Other factors such as FDR, VAP, ROA, NOM, and CAR even though not statistically differ, but the average of all variable used in this study showed that listed Islamic banks have better performance than the unlisted ones. Therefore, being listed Islamic bank is a concern for existing unlisted Islamic banks. Being a bank which goes public make the bank will always try to give a good signal to investors through a sound financial performance.

\section{References}

Al Arif, M.N.R. (2015). Keterkaitan Kebijakan Pemisahan Terhadap Tingkat Efisiensi Pada Industri Perbankan Syariah di Indonesia. Jurnal Keuangan dan Perbankan. Vol. 19 (2): 295-304.

Anggraini, M. et.al. (2015). Analisis Kinerja Keuangan Bank Konvensional Dan Bank Syariah Dengan Menggunakan Pendekatan RGEC (Studi pada PT. BRI, Tbk dan PT. BRI Syariah Periode 2011-2013). Jurnal Administrasi Bisnis (JAB). Vol. 27 No. 1: 1-6.

Antonio, M.S. (2011). Bank Syariah Dari Teori ke Praktik.Jakarta: Gema Insani Press.

Astuti, H.D. (2015). Analisa Perbandingan Kinerja Bank Asing dan Bank Nasional dengan Rasio Keuangan. Jurnal Magister Manajemen. Vol.01, No.1: 19-29.

Bank Indonesia. (2011). PBI Nomor 13/1/PBI/2011 Tentang Penilaian Tingkat Kesehatan Bank Umum.

Bini, L. et.al. (2011). Signalling Theory and Voluntary Disclosure to The Financial Market (evidence from the profitability indicators published in the annual report), Paper presented at the 34th EAA Annual Congress, 20-22 April 2011.

Fitriana, N. et.al. (2015). Tingkat Kesehatan Bank BUMN Syariah dengan Bank Umum Konvensional: Metode RGEC (Risk Profile, Good Corporate Governance, Earning and Capital). Jurnal Ekonomi dan Bisnis. Vol. 17 (2): 1-12.

Ghozali, I. (2011). Aplikasi Analisis Multivariate dengan Program SPSS. Edisi 5. Semarang: Badan Penerbit Universitas Diponegoro.

Hanif, M. (2011). Differences and Similarities in Islamic and Conventional Banking, International Journal of Business and Social Science. Vol. 2 No. 2: 166-175.

Healy, P.M. \& K.G. Palepu. (2001). Information asymmetry, corporate disclosure, and the capital markets: A review of the empirical disclosure literature. Journal of Accounting and Economics. Vol. 31: 405-440.

Kuncoro, M. (2002). Manajemen Perbankan. Yogyakarta: Fakultas Ekonomi UGM. 
Lupa, W. et.al. (2016). Analisis Perbandingan Tingkat Kesehatan Perbankan Syariah dengan Perbankan Konvensional dengan Metode CAMEL. Jurnal Berkala Ilmiah Efisiensi. Vol. 16 (1): 694-705.

Putri, I.D.A.D.E. \& I.G.A.E. Damayanti. (2013). Analisis Perbedaan Tingkat Kesehatan Bank Berdasarkan Risk profile,Good Corporate Governance, Earnings, \&Capital pada perusahaan Perbankan Besar dan Kecil. E-Jurnal Akuntansi Universitas Udayana 5.2 (2013): 483-496.

Rivai, V. et.al. (2007). Bank and Financial Institution Management. Jakarta: PT. RajaGrafindo Persada.

Rotinsulu, D.P. et.al. (2015). The Analyse of Risk-Based Bank Rating Method On Bank's Profitability in State-Owned Banks. Jurnal EMBA. Vol.3 No.1: 95106.

Sekaran, U. (2009). Metodologi Penelitian Untuk Bisnis, 4th edition Buku 1. Jakarta: PT. Salemba Empat.

Simorangkir, C. (2003). Manajemen Keuangan. Jakarta: Badan Penerbitan FE Universitas Indonesia.

Sofyan, Y.P.P. \& A.H. Anggono. (2015). The Effect of Risk Based Bank Rating Components towards Earnings on 19 Indonesian Commercial Banks in Period 2005-2014. Australian Journal of Accounting, Economics and Finance. Volume 1. Issue 1: 56-65. 